УДК 657

\title{
ОРГАНІЗАЦІЯ ОБЛІКУ ОПЛАТИ ПРАЦІ НА ПІДПРИЕМСТВАХ: ПРОБЛЕМИ ТА ШЛЯХИ ЇХ ВИРІШЕННЯ
}

\section{ORGANIZATION OF ACCOUNTING FOR REMUNERATION AT ENTERPRISES: PROBLEMS AND WAYS TO SOLVE THEM}

\author{
Гуріна Наталія Валеріївна \\ кандидат економічних наук, доцент, \\ Університет державної фріскальної служби України \\ ORCID: https://orcid.org/0000-0001-9433-069X \\ Бестюк Анастасія Миколаївна \\ студентка \\ Навчально-науковий інститут обліку, аналізу та аудиту \\ Університету державної фріскальної служби України \\ ORCID: https://orcid.org/0000-0002-7776-5496 \\ Gurina Nataliya, Bestiuk Anastasia \\ University of the State Fiscal Service of Ukraine
}

\begin{abstract}
У статті розглянуто організацію обліку оплати праці. Досліджено теоретичні основи заробітної плати, як ключового чинника в роботі працівників. Визначено, що лежить в основі організації обліку заробітної плати. Описано фрорми та види заробітної плати. Окреслено, які чинники впливають на фрорми та види оплати праці, розглянуто класифрікацію фрорм та видів оплати праці. Розкрито їх переваги та недоліки. Описано ознаки оптимальності обліку оплати праці. Зазначено нормативні документи, відповідно до яких здійснюється регулювання обліку заробітної плати. Проаналізовано списковий склад працівників, а також визначено якісні та кількісні характеристики трудового персоналу. Доведено, що організація обліку є інструментом матеріального заохочення працівників. Крім того, визначено основні проблеми та розглянуто шляхи оптимізації обліку заробітної плати.
\end{abstract}

Ключові слова: заробітна плата, організація бухгалтерського обліку, системи оплати праці, фрорми оплати праці, аналітичні рахунки.

В статье рассмотрено организацию учета оплаты труда. Исследовано теоретические основы заработной платы, как ключевого фактора в работе сотрудников. Определено, что лежит в основе организации учета заработной платы. Описаны формы и виды заработной платы. Определены, какие фракторы влияют на фрормы и виды оплаты труда, рассмотрена классиорикация форм и видов оплаты труда. Раскрыто их преимущества и недостатки. Описаны признаки оптимальности учета оплаты труда. Указано нормативные документы, согласно которым осуществляется регулирование учета заработной платы. Проанализирован списочный состав работников, а также определены качественные и количественные характеристики трудового персонала. Доказано, что организация учета является инструментом материального поощрения работников. Кроме того, определены основные проблемы учета заработной платы и рассмотрены пути его оптимизации.

Ключевые слова: заработная плата, организация бухгалтерского учета, системы оплаты труда, фрормы оплаты труда, аналитические счета.

The article considers the organization of payroll accounting. It is determined that underlies the organization of payroll accounting. Wages are one of the most difficult economic categories and one of the most important socio-economic phenomena. Since it is, on the one hand, the main (and often the only) source of income for employees, the basis of material well-being of their families, and on the other hand, for employers is a significant share of production costs and an effective means of motivating employees to achieve goals. organization of wages and the formation of its level together with issues of employment are the basis of social and labor relations in society, 
because they include the pressing interests of all participants in the labor process..Simplicity, logic and accessibility of forms and systems of remuneration, providing broad awareness of employees about the essence of remuneration systems. An incentive becomes an incentive only when employees have information about it, and it is understood by them as non-specialists in the field of labor economics. Performers must have a clear idea of the specific cases in which wages, ie the level of their material well-being, will increase. The extremely important role of wages in the mechanism of functioning of a market economy is due to the fact that it must perform the following basic functions: reproductive, stimulating, optimizing, regulatory, social Forms and types of wages are described. It is outlined what factors influence the forms and types of remuneration. The classification of forms and types of remuneration is given. The advantages and disadvantages of forms of remuneration are noted. The process of formation of the remuneration system is determined. The signs of optimal payroll accounting are described. The normative documents according to which the regulation of the accounting of a salary is carried out are specified. The list of employees is analyzed. Qualitative and quantitative characteristics of labor personnel are determined. Primary documents and required details are set. The main problems that arise during pay are identified. Ways to optimize payroll accounting are presented. It is proposed to open sub-accounts. The list of analytical accounts which it is expedient to open for detailing of the account 66 "Calculations on payments to employees" is described.

Keywords: wages, organization of accounting, remuneration systems, forms of remuneration, analytical accounts.

Постановка проблеми. В ринкових умовах господарювання оплата праці базується на двох головних принципах - економічній свободі ринкових суб'єктів господарювання та їхній повній відповідальності за результати діяльності. Тому дедалі актуальнішими стають питання організації обліку оплати праці, оскільки величина заробітної плати повністю залежить від ефективності роботи працівників та виконує фрункцію матеріального стимулу для них.

Аналіз останніх досліджень і публікацій. Дослідженням організації оплати праці займались такі вчені як: Ф.Ф. Бутинець, B.І. Гринчуцький, Н.М. Гудзенко, Л.В. Гуцаленко, Я.П. Іщенко, М.В. Мудрик, Н.Л. Правдюк, І.Б. Садовська та інші. Проте, незважаючи на значну кількість наукових праць, слід відзначити, що $€$ деякі особливості обліку оплати праці, які потребують вирішення.

Виділення невирішених раніше частин загальної проблеми. Варто зауважити, що потребує подальших досліджень вивчення законодавчої бази для організації обліку праці; вибір фоорм та систем оплати праці, шляхів їх удосконалення. Досягається це завдяки удосконаленню методологічних правил та фріскальних процедур щодо облікового відображення розрахунків з оплати праці, а також деталізації синтетичних та аналітичних рахунків.

Формулювання цілей статті. Метою дослідження $€$ вивчення методів організації ведення бухгалтерського обліку виплат працівникам та шляхи їх удосконалення.

Виклад основного матеріалу дослідження. Організація обліку оплати праці $€$ основою соціально-трудових відносин різних категорій осіб: працівників, роботодавців та держави, яка наповнює соціальні фонди шляхом сплати податків та платежів, базою для нарахування яких $€$ виплати працівникам. Функціонування системи оплати праці, потребує організації інсрормаційного забезпечення, тобто фрормування певного блоку інфрормації, тому першочерговим об'єктом організації обліку є організація переліку показників. Склад і структура інфрормації, визначаються потребами управління фондом оплати праці та розрахунками з працівниками. Також на них впливають інші взаємопов'язані чинники:

- зміст та обсяги фрінансово-господарської діяльності;

- склад показників фрінансової та статистичної звітності;

- структура управління та виробництва.

Під час реєстрації показників та їх відображення в обліку невід'ємною умовою забезпечення оптимальності інорормації є застосування принципів цілісності та реєстрації [1], крім того беруться до уваги якісні характеристики інформації, їі цінності для управління, переваги при вирішенні певних управлінських завдань. Це дасть змогу ссрормувати оптимальну за складом і змістом інфрормацію, уникати надлишкової інорормації, забезпечить реєстрацію показників, що безпосередньо впливають на процеси господарювання, задовольняють потреби управління та дадуть змогу вирішити поставлені завдання [2].

Для інсрормації з обліку праці та її оплати найважливішими ознаками оптимальності $€$ [2]:

1) достовірність - забезпечення адекватності показників, що характеризують витрати праці (кількість відпрацьованого робочого часу та виробітку) та якісні характеристики працівників (посада, професія, розряд, рівень квалісрікації); 
2) багатократність використання - багаторазове використання у декількох облікових процедурах (облік заробітної плати в розрізі працівників та у розрізі структурних підрозділів, видів і фрорм заробітної плати, облік розрахунків з працівниками, облік єдиного соціального внеску, облік податку 3 доходів орізичних осіб), а також їх застосування для аналізу та контролю заробітної плати;

3) своєчасність - забезпечення вчасного нарахування і виплати заробітної плати працівникам, а також оперативного прийняття ефрективних управлінських рішень;

4) системність - зв'язок показників первинного обліку (документів) з показниками аналітичного і синтетичного обліку та звітності.

У вітчизняній нормативній базі питання обліку та звітності за виплатами працівникам регулюються Положенням (стандартом) бухгалтерського обліку 26 «Виплати працівникам» [3]. Необхідно зазначити, що однозначного визначення поняття «виплати працівникам» П(С)БО 26 не надає, тільки деталізує, які виплати до якої групи включаються, та дає визначення окремих термінів. Виплати працівникам, відповідно до П(С)БО 26, поділяють на п'ять груп.

Існуючі форми оплати праці мають підвиди, які забезпечують відповідність виробничій ситуації, особливостям мотивації пра- цівників певного підприємства тощо. Основні характеристики наявних систем оплати праці представлено в табл. 1.

В ринкових умовах господарювання, особливо на малих підприємствах доцільно застосовувати прості системи оплати праці. Вибір фрорми оплати праці залежить від особливостей підприємства: галузевої діяльності, організаційно-правової фрорми, місця розташування, системи оподаткування. Основні переваги та недоліки погодинної та відрядної оплати праці наведено в табл. 2.

Під час вибору фрорми оплати праці потрібно враховувати психологічні, соціальні чинники, чинники пов'язані з мотивацією, відносини в колективі, економічні фрактори. Відповідно до Закону України «Про оплату праці» [5] підприємства мають право самостійно обирати форми та системи оплати праці. Вказані вище форми та системи детально прописують в колективних договорах, генеральних, галузевих угодах, положеннях про преміювання. Також деякі елементи можуть бути прописані в контракті, який укладається з працівником.

Процес фрормування системи оплати праці, іï розроблення та реалізація передбачають чітке регламентування в послідовності, що зображена на рис. 1.

Основним джерелом даних про розрахунки за виплатами працівникам $є$ система бухгал-

Форми і системи оплати праці на підприємстві

Таблиця 1

\begin{tabular}{|c|c|c|}
\hline \multirow[b]{2}{*}{ Форми } & Погодинна & Відрядна \\
\hline & в основі - фрактично відпрацьований час & $\begin{array}{l}\text { в основі - фрактично вироблена кількість } \\
\text { продукту }\end{array}$ \\
\hline \multirow{4}{*}{$\begin{array}{l}\text { Прості } \\
\text { системи }\end{array}$} & проста погодинна & пряма відрядна \\
\hline & $\begin{array}{l}\text { оклад (або погодинна чи денна ставка) } \\
\text { за відпрацьований час }\end{array}$ & $\begin{array}{l}\text { оплата - про розцінці за кожну одиницю } \\
\text { продукту }\end{array}$ \\
\hline & погодинно-преміальна & відрядно-преміальна \\
\hline & $\begin{array}{l}\text { оклад (або погодинна чи денна ставка) } \\
\text { за відпрацьований час + премія }\end{array}$ & $\begin{array}{l}\text { за кількість + премія за виконання } \\
\text { (перевиконання) плану }\end{array}$ \\
\hline \multirow{6}{*}{$\begin{array}{l}\text { Складні } \\
\text { системи }\end{array}$} & почасова з системою мотивації & відрядно-прогресивна \\
\hline & \multirow{5}{*}{$\begin{array}{l}\text { Заробітна плата = постійна частина - } \\
\text { оклад (погодинна або денна ставка); } \\
\text { змінна частина (сума регулярних } \\
\text { премій) - складна система преміювання } \\
\text { (мотивації), наприклад на основі } \\
\text { ключових показників } \\
\text { едективності); } \\
\text { нерегулярні премії - за певні ініціативи } \\
\text { працівника, які неможливо запланувати } \\
\text { й передбачити заздалегідь, виконання в } \\
\text { строк певного складного завдання. }\end{array}$} & $\begin{array}{l}\text { розцінки за продукт збільшуються по мірі } \\
\text { виконання плану }\end{array}$ \\
\hline & & непряма відрядна \\
\hline & & $\begin{array}{l}\text { оплата працівника (зазвичай } \\
\text { допоміжного) залежить від результату } \\
\text { роботи основних працівників }\end{array}$ \\
\hline & & акордна \\
\hline & & $\begin{array}{l}\text { оплата не за одиницю продукту, а за } \\
\text { певний етап (акорд), комплекс робіт }\end{array}$ \\
\hline
\end{tabular}


Переваги та недоліки простих систем оплати праці

\begin{tabular}{|c|c|c|}
\hline Порівняння & Погодинна & Відрядна \\
\hline Переваги & $\begin{array}{l}\text { - підходить для більшості підприємств, } \\
\text { особливо в торгівлі, сфері надання } \\
\text { послуг, здебільшого єдино можлива для } \\
\text { осрісних працівників та адмінперсоналу; } \\
\text { - застосовується у виробництвах, де } \\
\text { основним критерієм є якість продукту } \\
\text { (за умов продуманої преміальної сис- } \\
\text { теми та системи контролю); }\end{array}$ & $\begin{array}{l}\text { - забезпечує мотивацію до збільшення } \\
\text { виробітку. Найчастіше - оплата робіт- } \\
\text { ників у промисловому виробництві, } \\
\text { сільському господарстві. Може бути } \\
\text { єдино прийнятний варіант, що змен- } \\
\text { шує конфрлікти в трудовому колективі. } \\
\text { Оплата більшою мірою залежить від } \\
\text { майстерності та вправності праців- } \\
\text { ника. }\end{array}$ \\
\hline Недоліки & $\begin{array}{l}\text { - не стимулює збільшення виробітку } \\
\text { (хоча все можна вирішити через сис- } \\
\text { тему премій); без належно продуманої } \\
\text { преміювальної системи може призво- } \\
\text { дити до зниження мотивації. }\end{array}$ & $\begin{array}{l}\text { - змагання за кількість виготовленої } \\
\text { продукції може стати причиною зн- } \\
\text { ження її якості; } \\
\text { - оскільки відрядна розцінка залежить } \\
\text { від норми виготовленої продукції, } \\
\text { тому це потребує певної кваліфікації } \\
\text { нормувальника; } \\
\text { - необхідність обґрунтованості усіх } \\
\text { встановлених норм. }\end{array}$ \\
\hline
\end{tabular}

Джерело: сфрормовано автором на основі [4]

Таблиця 2

ідентифікація управлінських рішень щодо управління

людським та інтелектуальним капіталом

визначення сукупності та повноти інформаційного

забезпечення управління досліджуваним об'єктом

3'ясування прийнятності нинішньої системи обліку

відносно забезпечення управлінського персоналу

необхідною інформацією

ідентифікація проблем функціонування підсистеми

обліку розрахунків за виплатами працівникам

наведення прийнятних пропозицій щодо покращення

облікового відображення розрахунків за виплатами

працівникам

Рис. 1. Процес формування системи оплати праці

Джерело: [6]

терського обліку. Підсистема облікового відображення розрахунків за виплатами працівникам містить всю необхідну інсоормацію про досліджуваний вид розрахунків.

Облік персоналу забезпечує надання інформації про склад працюючих в розрізі отриманої освіти та присвоєної кваліфрікації, віку, профресій, стажу роботи та інших показників, які відіграють важливу роль при нарахуванні заробітної плати.

Аналіз даних про персонал дає можливість виділити головні кількісні та якісні характерис- 
тики трудового колективу, знайти резерви для подальшого покращення щодо чисельності та якості його складу, цілеспрямовано фрормувати команду управлінців та виконавців високого рівня, які здатні забезпечити успішне фрункціонування й тривале існування підприємства.

Первинні документи з обліку праці та її оплати повинні бути сорормовані у момент, коли відбулася відповідна господарська операція або безпосередньо після ії̈ завершення. Документальне оформлення господарських операцій, у тому числі з праці та її оплати, може здійснюватись із використанням виготовлених самостійно бланків, які повинні обов'язково містити реквізити типових або спеціалізованих фоом і відповідати основним вимогам до їх складання:

- своєчасність;

- достовірність показників;

- заповнення всіх реквізитів;

- правильність оформлення [7].

Основним первинним документом для обліку використання робочого часу, інфрормація якого використовується при погодинній оплаті, $€$ «Табель обліку використання робочого часу» (типова фрорма № П-5). «Табель» застосовується для обліку використання робочого часу, контролю за дотриманням працівниками встановленого режиму робочого часу, розрахунку заробітної плати та складання статистичної звітності. Табельний облік ведеться за місцем основної роботи в бригадах, на фермах, в майстернях і т.д. обліковцем даного підрозділу або іншими уповноваженими особами.

Основним джерелом даних про розрахунки за виплатами працівникам є система бухгалтерського обліку (результат ії фрункціонування - відповідні показники у фрінансовій, статистичній та податковій формах звітності). Підсистема облікового відображення розрахунків за виплатами працівникам містить всю необхідну інформацію про досліджуваний вид розрахунків, що дає можливість стверджувати про перспективу задоволення інорормаційних потреб управлінського персоналу шляхом вивчення інфрормаційних потреб та відповідного налаштування облікового інструментарію.

В процесі дослідження було виділено такі проблеми бухгалтерського обліку розрахунків суб'єкта господарювання за виплати працівникам, як:

- документування операцій з нарахування заробітної плати та утримань з неї;
- визнання та оцінки зобов'язань, що виникають при нарахуванні заробітної плати;

- поділу виплат працівникам на види;

- організації синтетичного та аналітичного обліку розрахунків за виплатами працівникам на бухгалтерських рахунках

- малої інформативності звітності щодо розрахунків за виплатами працівникам;

- узгодженості норм національних та міжнародних стандартів обліку щодо розрахунків за виплатами працівникам;

- узгодженості фрорм фрінансової, податкової, спеціальної та статистичної звітності щодо розрахунків за виплатами працівникам.

Для вирішення наведеного комплексу проблем доцільно:

1) визначити на національному рівні правила ідентифікації, визнання та оцінки, класифікації зобов'язань перед працівниками від виконання програм (програми виплат з визначеним внеском; програми виплат за участю кількох роботодавців; програми виплат по закінченню трудової діяльності; програми виплат інструментами власного капіталу тощо) у форматі методичних рекомендацій;

2) дотримуватись норм П(С)БО 26 «Виплати працівникам» щодо поділу виплат персоналу: «поточні виплати, виплати по закінченні трудової діяльності, виплати при звільненні, виплати інструментами власного капіталу підприємства, інші довгострокові виплати». Узгодити наведені види виплат із тими, що наведені в Інструкції зі статистики заробітної плати [8];

3) використовувати норми П(С)БО 26 «Виплати працівникам» [3] в цілому при організації бухгалтерського обліку розрахунків за виплатами працівникам та частково при побудові системи управлінського обліку як складового елемента інформаційного забезпечення управління трудовими ресурсами суб'єкта господарювання.

В основі удосконалення системи бухгалтерських рахунків 3 обліку розрахунків за виплатами працівникам лежить поділ потенційних винагород за виконувану роботу. Проаналізовані праці науковців свідчать, що при ідентифікації субрахунків та аналітичних рахунків з обліку оплати праці слід дотримуватися чинних нормативно-правових актів, а саме Кодексу законів України про працю [8], Закону України «Про оплату праці» [5], Інструкції зі статистики заробітної плати [9], П(С)БО 26 «Виплати працівникам» тощо.

Для вирішення наявних проблем потрібно ідентифікувати ще низку важливих фракторів, 


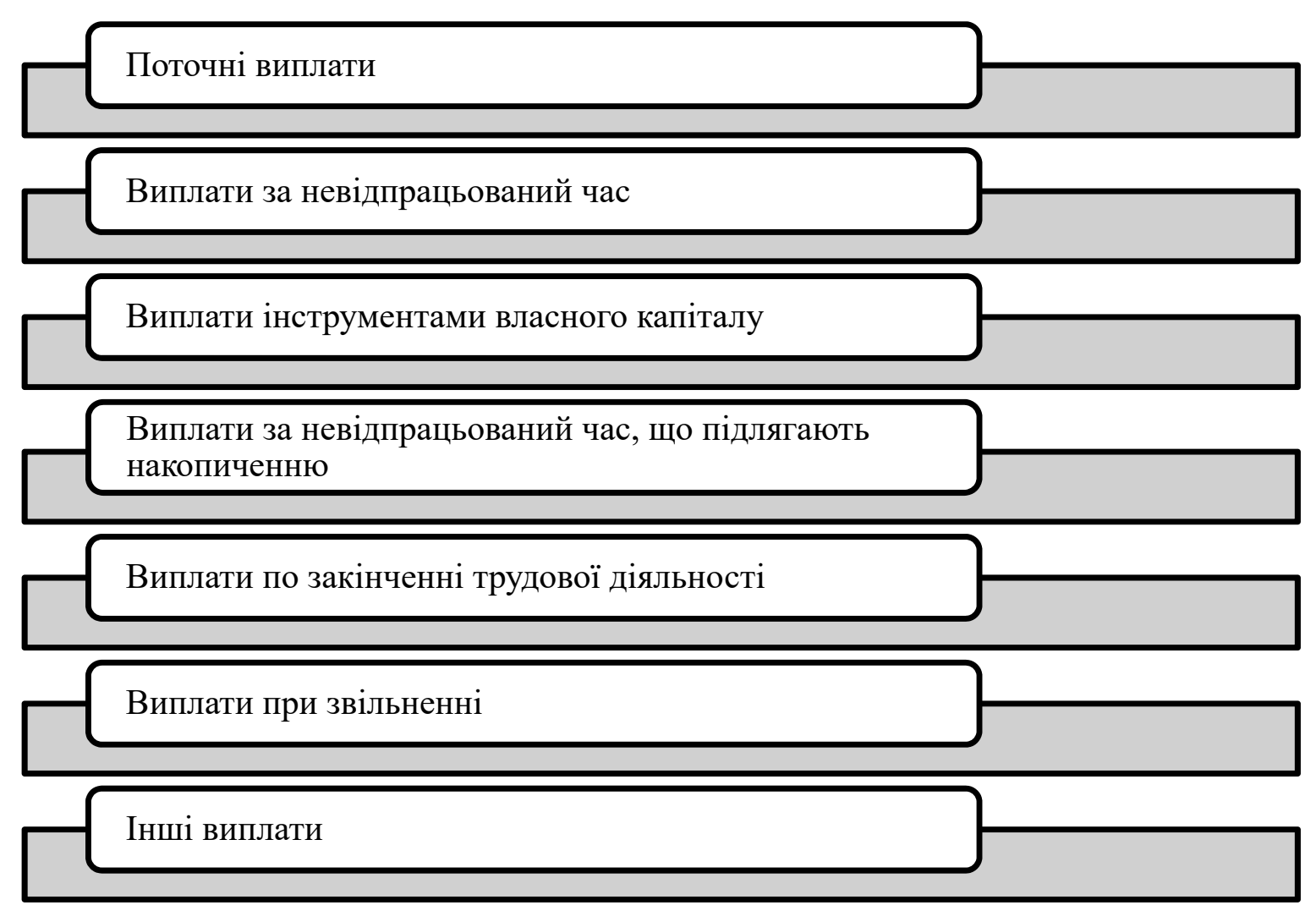

Рис. 2. Рахунки 2-го порядку до субрахунків рахунку 66 «Розрахунки за виплатами працівникам» [7]

що мають вплив на організацію аналітичного обліку розрахунків за виплатами працівникам. До них слід віднести: організаційну та виробничу структуру суб'єкта господарювання; інформаційні потреби управлінського персоналу; кваліфікаційну структуру персоналу суб'єкта господарювання тощо. Тому, оптимальним $€$ виділення аналітичних ознак виходячи із інформаційних потреб управління, належності персоналу до центрів відповідальності або ж структурних підрозділів та виходячи із видів виплат працівникам.

Зважаючи на необхідність адаптації вітчизняної системи обліку до міжнародних стандартів доцільним $€$ відкриття аналітичних рахунків 2-го порядку до субрахунків рахунку 66 «Розрахунки за виплатами працівникам», які б деталізували види потенційних винагород, що можуть бути отримані персоналом суб'єкта господарювання та не підлягають накопиченню (рис. 2).

Запропонована система аналітичного обліку розрахунків за виплатами працівникам забезпечить раціоналізацію процесу складання статистичної звітності (Звіт із праці), податкової звітності (Податковий розраху- нок сум доходу, нарахованого (сплаченого) на користь фрізичних осіб, і сум утриманого $з$ них податку) та спеціальної звітності (Звіт про суми нарахованої заробітної плати (доходу, грошового забезпечення, допомоги, надбавки, компенсації) застрахованих осіб та суми нарахованого єдиного внеску на загальнообов'язкове державне соціальне страхування), створить можливості для оперативного реагування на зміни в податковому законодавстві через продукування системою обліку аналітичних даних щодо нарахованих різноманітних за змістом виплат персоналу.

Висновки. При розгляді напрямів удосконалення обліку розрахунків за виплатами працівникам необхідно зазначити фракт наявності методологічних правил та фріскальних процедур щодо облікового відображення досліджуваних операцій, а в цілях підвищення інфрормаційної цінності підсистеми обліку розрахунків за виплатами працівникам доцільно удосконалити систему рахунків синтетичного й аналітичного обліку та змістовий підхід до розкриття відповідної інфрормації (у фрорматі фрінансової та управлінської звітності). 


\section{СПИСОК ВИКОРИСТАНИХ ДЖЕРЕЛ:}

1. Машевська А.А. Теоретичне підґрунтя організації оплати праці суб'єктів господарювання. Ефективна економіка. 2019. № 11. URL: http://www.economy.nayka.com.ua/pdf/11_2019/189.pdf (дата звернення: 04.01.2021).

2. Онищенко А.В. Підвищення мотивації праці персоналу підприємства. Науковий вісник Луганського національного аграрного університету. 2019. № 1. URL: http://localhost:8080/xmlui/handle/123456789/771 (дата звернення: 04.01.2021).

3. Положення (стандарт) бухгалтерського обліку 26 «Виплати працівникам» : наказ Міністерства фінансів України 28.10.2003 р. № 601.137 зі змінами та доповненнями. URL: http://zakon3.rada.gov.ua/laws/show/ z1025-03 (дата звернення: 04.02.2021).

4. Онищенко В.П. Форми оплати праці в Україні. Головбух. 2020. Вип. 8. URL: https://www.golovbukh.ua/ article/7319-formi-oplati-prats (дата звернення: 04.01.2021).

5. Про оплату праці: Закон України від 24 березня 1995 р. № 108/95-BP. Верховна Рада України. URL: https://zakon.rada.gov.ua/laws/show/108/95-\%D0\%B2\%D1\%80\#Text (дата звернення 03.02.2021).

6. Попова В.Д., Колотило Ю.І. Облік оплати праці: проблеми та напрями удосконалення облікового забезпечення управління персоналом. Молодий вчений. 2019. № 10(74). URL: http://molodyvcheny.in.ua/files/ journal/2019/10/149.pdf (дата звернення: 04.01.2021).

7. Миронова Ю.Ю., Панасенко В.А. Проблеми організації обліку розрахунків з оплати праці на підприємстві. Бухгалтерський облік, аналіз та аудит. 2016. № 1(56). URL: irbis-nbuv.gov.ua/cgi-bin/irbis_nbuv/ cgiirbis_64.exe\%3FC21COM\%3D2\%26I21DBN\%3DUJRN\%26P21DBN\%3DUJRN\%26IMAGE_FILE_mage_file_ name\%3DPDF/econrig_2016_1_20.pdf+\&cd=3\&hl=uk\&ct=clnk\&gl=ua (дата звернення: 10.02.2021).

8. Кодекс законів про працю України № 2005-VIII від 06.04.2017-VIII. URL: http://zakon1.rada.gov.ua/laws/ show/322-08 (дата звернення: 10.02.2021).

9. Інструкція зі статистики заробітної плати : наказ Державного комітету статистики України від 13.01.2014 p. № 5 зі змінами та доповненнями. URL: http://zakon0.rada.gov.ua/laws/show/z0114-04 (дата звернення: 20.10.2019).

10. Інструкція про застосування Плану рахунків бухгалтерського обліку активів, капіталу, зобов'язань і господарських операцій підприємств і організацій: Наказ Міністерства фрінансів України від 31.05.2019 № 226 зі змінами та доповненнями. URL: https://zakon.rada.gov.ua/laws/show/z0893-99 (дата звернення: 20.10.2019).

\section{REFERENCES:}

1. Mashevska A.A. (2019) Teoretychne pidgruntia orhanizatsii oplaty pratsi subiektiv hospodariuvannia [Theoretical basis of the organization of remuneration of business entities]. Effective Economy (electronic journal), vol. 11. Available at: http://www.economy.nayka.com.ua/pdf/11_2019/189.pdf (accessed 25 January 2021).

2. Onyshchenko A.V. (2019) Pidvyshchennia motyvatsii pratsi personalu pidpryiemstva [Increasing the Motivation of the Personnel of the Enterprise] (unpublished).

3. Polozhennia (standarty) bukhhalterskoho obliku 26 «Vyplaty pratsivnykam» [Accounting Provisions (Standards) 26 "Employee Benefits"]: nakaz Ministerstva finansiv Ukrainy 28 October 2003, vol. 601. 137 zi zminamy ta dopovnenniamy. Available at: http://zakon3.rada.gov.ua/laws/show/z1025-03 (accessed 10 February 2021).

4. Onyshchenko V.P. (2020) Formy oplaty pratsi v Ukraini [Forms of Remuneration In Ukraine]. Holovbukh [Chief Accountant] (electronic journal), vol. 8. Available at: https://www.golovbukh.ua/article/7319-formi-oplati-prats (accessed 10 February 2021).

5. Pro oplatu pratsi [On remuneration]: Zakon Ukrainy, pryiniatyi Verkhovnoiu Radoiu Ukrainy 24 March 95, vol. 108/95-VR. Available at: https://zakon.rada.gov.ua/laws/show/108/95-\%D0\%B2\%D1\%80 (accessed 10 February 2021).

6. Popova V.D. Kolotylo Yu.I. (2019) Oblik oplaty pratsi problemy ta napriamy udoskonalennia oblikovoho zabezpechennia upravlinnia personalom [Payroll accounting: problems and areas of improvement of accounting support for personnel management]. Molodyi Vchenyi [Young scientist] (electronic journal), vol. 10(74). Available at: http://molodyvcheny.in.ua/files/journal/2019/10/149.pdf (accessed 12 February 2021).

7. Myronova Yu.Yu.Panasenko V.A. (2016) Problemy orhanizatsii obliku rozrakhunkivz oplaty pratsina pidpryiemstvi [Problems of the organization of the account of calculations on payment of work at the enterprise]. Bukhhalterskyi oblik analiz ta audit [Accounting, analysis and audit] electronic journal), vol. 1(56). Available at: irbis-nbuv.gov.ual cgi-bin/irbis_nbuv/cgiirbis_64.exe\%3FC21COM\%3D2\%26I21DBN\%3DUJRN\%26P21DBN\%3DUJRN\%26IMAGE_ FILE_DOWNLOAD\%3D1\%26Image_file_name\%3DPDFleconrig_2016_1_20.pdf+\&cd=3\&hl=uk\&ct=clnk\&gl=ua (accessed 10 February 2021). 
8. Kodeks zakoniv pro pratsiu Ukrainy [Code of Labor Laws of Ukraine], vol. 2005-VIII 06 April 2017 - VIII. Available at: http://zakon1.rada.gov.ua/laws/show/322-08 (accessed 10 February 2021).

9. Instruktsiia zi statystyky zarobitnoi platy [Instruction on statistics of wages]: nakaz Derzhavnoho komitetu statystyky Ukrainy 13 January 2014, vol. 5, zi zminamy ta dopovnenniamy. Available at: http://zakon0.rada.gov.ua/ laws/show/z0114-04 (accessed 11 February 2021).

10. Instruktsiia pro zastosuvannia Planu rakhunkiv bukhhalterskoho obliku aktyviv, kapitalu, zobov'iazan i hospodarskykh operatsii pidpryiemstv i orhanizatsii [Instruction on application of the Plan of accounts]: Nakaz Ministerstva finansiv Ukrainy 31 May 2019, vol. 226, zi zminamy ta dopovnenniamy. Available at: https://zakon.rada.gov.ua/laws/show/z0893-99 (accessed 10 February 2021). 